\title{
Vývoj koncepce výchovy v přírodě v kontextu vývoje mezinárodního a její vymezení v České republice
}

\author{
Jan Neuman a, Ivana Turčová ${ }^{a}$, Tomáš Brtník ${ }^{a}$, \\ Andrew J. Martin ${ }^{\mathrm{b}}$ \\ ${ }^{a}$ Univerzita Karlova, Fakulta tělesné výchovy a sportu, Katedra sportů v př́rodě \\ ${ }^{\mathrm{b}}$ Massey University, New Zealand
}

Redakci zasláno 22. 1. 2021 / upravená verze obdržena 14. 5. 2021 /

/ k uveřejnění přijato 15. 5. 2021

\begin{abstract}
Abstrakt: $\mathrm{V}$ české akademické sféře se začal zvyšovat zájem o přesnější charakteristiku výchovy v prŕrodě v souvislosti s akreditováním studijních směrů, specializací ći oborů pod názvy „Aktivity v přírodě“ či „Výchova v přírodě“ nebo zařazováním předmětů podobných názvů do oborů pedagogického zaměření. Cílem této přehledové studie je předložit české odborné veřejnosti vývoj koncepce výchovy v př́rodě $\mathrm{v}$ českém prostředí $\mathrm{v}$ kontextu vývoje mezinárodního. Vybrané zahraniční koncepce výchovy v prŕrodě jsou analyzovány a kriticky zhodnoceny. Dále se pokoušíme o vymezení výchovy $\mathrm{v}$ přírodě $\mathrm{v}$ České republice. Porovnáváme-li zaměření naší práce s různými teoriemi, přikláníme se ke strategii, kterou zvolil tým amerických odborníků vedený Kenem Gilbertsonem v roce 2006.
\end{abstract}

Klíčová slova: aktivity v přírodě, ekologická výchova, osobnostní a sociální rozvoj, učení v př́rodě

O výchově v přírodě (outdoor education) existuje rozsáhlá zahraniční literatura, která $\mathrm{v}$ několika příspěvcích odkazuje i na historické kořeny $\mathrm{v}$ naší zemi. Témata blízká výchově v prŕrodě a posuzování vztahů člověka k př́rodě podnítila $\mathrm{v}$ novém tisíciletí kniha amerického novináře Richarda Louva s názvem Last child in the woods a podnázvem Saving our children from nature-deficit disorder (2005). Publikace iniciovala ve vyspělých zemích mnoho výzkumů ověřujících prospěšnost pohybu v přírodě pro různé skupiny populace. Zájem o oblast výchovy v prŕírodě je v souladu se snahou vyspělých zemí, jejichž populace čelí nedostatku pohybové činnosti a ztrátě kontaktů s přírodním prostředím.

V českých zemích jsme mohli registrovat poměrně velký počet publikací i odborných prací, které v průběhu 80 . a 90 . let 20 . století zmiňovaly výchovu 
v přírodě. Později se toto téma objevuje spíše jako součást problematiky spojované se zážitkovou pedagogikou.

V české akademické sféře se začal zvyšovat zájem o přesnější charakteristiku výchovy $\mathrm{v}$ prrírodě $\mathrm{v}$ souvislosti s akreditováním studijních směrů, specializací či oborů pod názvy „aktivity v přírodě“ či „výchova v přírodě“ nebo zařazováním předmětů podobných názvů do oborů pedagogického zaměření na vysokých školách.

V mezinárodním prostředí nabral na síle zájem o učení v přírodě (outdoor learning). Úspěšné projekty se rozvíjejí v zahraničí a také v ČR, kde lze nalézt mnohá společná témata vztahující se $\mathrm{k}$ učení $\mathrm{v}$ př́ŕrodě a $\mathrm{k}$ oblasti výchovy $\mathrm{v}$ prírodě.

Při hledání místa výchovy $\mathrm{v}$ př́rodě $\mathrm{v}$ pedagogické oblasti jsme si vědomi toho, že je velmi obtížné dosáhnout dohody na jednotném používání jakéhokoliv nosného termínu. To plně potvrzují publikace I. Turčové (Turčová, 2005; Turčová, 2007), která se v minulých letech terminologií související s tzv. outdoorovými aktivitami výzkumně zabývala. Definice termínů jsou ovlivněny mnoha faktory, jako je doba, ve které byly vytvořeny, kulturní a národní prostředí, ve kterém byly vytvořeny, či situace, ve které byl termín použit.

Mnohdy narážíme na potíže s jednotným výkladem termínů, jako je pedagogika, výchova, zkušenost či prožitek. Nepřesnosti vznikají v překladech do angličtiny a $\mathrm{z}$ angličtiny, která je ve výchově v přírodě vedoucím odborným jazykem. Dalším nedostatkem je omezená komunikace mezi jednotlivými obory, kterých se může tematika výchovy v př́rodě dotýkat (např. tělesná výchova, environmentální a ekologická výchova, terénní výuka různých předmětů na ZŠ a SŠ, zkušenostní učení, zážitková pedagogika aj.).

Vzestup člověka byl po miliony let vázán na př́rodní prostředí. Výchova v přírodě by lidem mohla pomoci řešit řadu problémů, které ovlivňují dnešní velmi rychlé technologické změny a ubývající kontakty mezi lidmi a přírodou.

\section{Historické zdroje výchovy v prrírodě}

Historické zdroje výchovy v př́rodě v České republice diskutujeme v mnoha předchozích publikacích (např. Martin et al., 2007, 2016; Neuman et al., 2018; Neuman \& Turčová, 2018), proto je zde nebudeme podrobněji popisovat a analyzovat. Soustředíme se především na vývoj koncepce výchovy v př́rodě po roce 1953. 


\subsection{Vývoj koncepce výchovy v prírodě v ČR}

V roce 1953 byla založena první vysoká tělovýchovná škola ITVS s Katedrou sportů v přírodě organizující sportovní kurzy v letní i zimní přírodě. Krátce poté začaly na všech vysokých školách pracovat katedry tělesné výchovy, jejichž důležitou rolí byla organizace letních a zimních kurzů, i zájmové oddíly turistiky a sportů v př́rodě.

O výchovné práci v přrírodě se začíná znovu hovořit po roce 1960 v tzv. tábornických školách (Snopek, 1969). V tomto období nenápadně propagoval nové směry výchovné práce i týdeník Mladý svět, založený v roce 1959. Instruktorský sbor tábornických škol byl tvořen učiteli i absolventy FTVS, jmenujme V. Vlčka, P. Klapuše, P. Tajovského, F. Dvořáka a další. Zkušeností z tábornických škol využili později i zakladatelé Prázdninové školy Lipnice (PŠL) A. Gintel a P. Tajovský (Neuman \& Hanuš, 2007).

Studie zabývající se výchovnými aspekty aktivit a pobytu v přírodě obvykle zapomínají na důležitou roli první vysoké tělovýchovné školy. Zde je třeba zmínit působení $P$. Tajovského, kterému bohužel osud nedopřál plné rozvinutí jeho schopností. Pod jeho vedením vzniklo v 70. letech více než 15 závěrečných prací, které se zabývaly výchovnými aspekty táboření, sportů a aktivit $\mathrm{v}$ prrírodě. To byly impulsy pro jeho následovníky.

Nové ideje pro rozvoj teorie a praxe výchovy $\mathrm{v}$ přírodě přicházely v 70. a 80. letech 20. století často ze zahraničí. Na Katedře sportů v př́rodě v té době vznikala pod vedením J. Neumana celá řada diplomových prací analyzující zkušenosti vyspělých zemí, z nich můžeme jmenovat Končelíkovou (1975), Honzíčkovou (1982), Ševčíkovou (1983), Lutovskou (1985) a další. Se závěrečnými pracemi byli seznamováni funkcionáři Svazu turistiky a také instruktoři PŠL.

O možných perspektivách výchovy v přírodě byla zahájena odborná diskuse na konferenci k 25. výročí založení FTVS UK v roce 1978 (Neuman, 1981). Zde byla myšlenka přebírání „západních“ zkušeností kritizována a mnohé práce pak byly povinně doprovázeny úvodem kritizujícím buržoazní přístupy. Situace se však postupně měnila. Během 80 . let 20 . století se k výchově v přírodě přihlásila Prázdninová škola Lipnice, která byla formálně řízená ÚV SSM. Téma výchovy v př́rodě zde mělo příznivou odezvu, což se projevilo v sérii konferencí inspirovaných programy PŠL. V tomto období můžeme zaznamenat ve vědeckém časopise Teorie a praxe tělesné výchovy sérii 
11 článků věnovaných novým přístupům $\mathrm{k}$ organizovanému pobytu $\mathrm{v}$ př́rodě, na kterých se podíleli A. Gintel, V. Břicháček, L. Blanařová, I. Slaměník, J. Gregor, O. Holec, V. Smékal, J. Neuman a J. Havel. Tento trend vyvrcholil uspořádáním mezinárodní konference v roce 1989, v předvečer sametové revoluce. Na konferenci tehdy spolupracovala PŠL s FTVS, za kterou se konference zúčastnil tehdejší děkan V. Hošek. Referát týkající se výchovy v přírodě přednesl J. Neuman a výchova $v$ přírodě zde byla charakterizována jako činnost, která:

- je orientována na výchovné využívání volného času;

- podporuje získávání nových zkušeností a zážitků;

- odkrývá nové sféry poznání a pochopení vazeb člověka a přírody;

- vede k rozvoji lidského potenciálu, který je předpokladem pro činnosti umožňující plnohodnotné uplatnění člověka ve společnosti.

Zájem narůstal a výchova $v$ prrírodě byla $v 90$. letech 20 . století předmětem několika konferencí pořádaných z iniciativy Nadace Pangea, kde A. Gintel založil výbor pro organizování odborných konferencí a seminářủ týkající se výchovy v přírodě. Př́spěvky účastníků konferencí se zabývaly novými pohledy na historii, na přínosy českých organizací i na využití nové programové nabídky.

Ve snaze hledat nové cesty se vytvořila v PŠL velká skupina zájemců o tzv. dobrodružnou výchovu, jejíž zaměření formulovali J. Neuman a J. Gregor. První část programu tohoto sdružení se zaměřila na vytváření možností pořádat dobrodružné akce v oblasti Bajkalského jezera. Realizovaly se tři výpravy a pak se kvůli „perestrojce“ v SSSR situace změnila a sekce dobrodružné výchovy pozvolna skončila svoji práci, nebot' po roce 1989 nastoupily jiné výzvy.

Počátkem 90. let vyšla také jedna z publikací autorů R. Hanuše a I. Jiráska (1996) s názvem Výchova v prírodě. Studie shrnovala pohledy na historii pobytu v přírodě u nás i v zahraničí. Přinesla také filozofický pohled na předpoklady nutné pro proces výchovy v přírodě. Další charakteristikou výchovy v př́rodě se však autoři nezabývali.

V roce 1996 publikoval J. Neuman na FTVS učební materiály nazvané Výchova $v$ prírodě, ve kterých podrobněji rozebíral novější koncepci amerického odborníka S. Priesta (1986) a rozšiřuje výše uvedenou charakteristiku výchovy $\mathrm{v}$ př́rodě takto: 
- je to metoda výchovy, která využívá přírodního prostředí pro všechny oblasti vzdělávání (tělesná výchova, pracovní výchova, výtvarná a estetická výchova, osobnostní a sociální rozvoj, ekologická výchova, biologie, geografie, historie, filozofie aj.);

- je to ideální prostředí umožňující sociální a emocionální rozvoj, který je podporovaný společným pobytem, společnou prací i společným řešením problémů v malých skupinách;

- opírá se o bezprostřední zážitky a zkušenosti, výchovné úsilí se zaměřuje nejenom na rozvoj dovedností a návyků, ale na rozvoj hodnotové orientace, formování postojů, jejich hodnocení a porozumění;

- podporuje tezi, že výchova nemůže být odtržená od života, což je v souladu s celostní výchovou;

- do procesu výchovy v přírodě jsou vtaženi všichni účastníci, nové zážitky a zkušenosti získávají žáci i učitelé;

- podmínky moderní společnosti vyvolávají stále naléhavější potřebu rozvoje výchovy v přírodě, je proto třeba nutná příprava učitelů, vedoucích, instruktorů a organizátorů, jež mají potřebné znalosti a ovládají potřebné dovednosti a techniky.

Z rozboru literatury je zřejmé, že v posledních letech nejvíce publikací týkajících se výchovy v př́rodě publikují v ČR učitelé a jejich spolupracovníci na Katedře sportů v př́rodě FTVS UK. Snaha přiblí̌zit se diskutované tematice se odrazila i v názvu jednoho z oddělení katedry Turistiku, sportů a výchovy v prrírodě, které připravilo učebnici Turistika a sporty $v$ přírodě: Přehled základních znalostí a dovedností pro výchovu v prrírodě (Neuman et al., 2000). Jedna z prvních kapitol je věnována výchově v př́rodě. Při její charakteristice vychází autorský kolektiv opět z prací S. Priesta (1986).

V dalším období jsme se snažili vyzvednout české předpoklady k modernímu pojetí výchovy v přírodě na mezinárodním poli. Autorský kolektiv J. Neuman, I. Turčová a A. J. Martin v posledních 20 letech publikoval desítky článků a prríspěvků na konferencích (např. Martin et al., 2007, 2016; Neuman et al., 2018). Hlavní tematikou byla česká historie pobytu $v$ přírodě, české pojetí turistiky, propagace českého př́stupu k hrám a tvorbě programů, tzv. dramaturgii. Snažili jsme se také předávat naše zkušenosti z mnohaleté př́ípravy a vedení kurzů, které by svojí skladbou mohly představovat alternativu ke kurzům Outward Bound. 
Téma výchovy v přírodě jsme zařazovali na pořad každé z devíti konferencí International Mountain and Outdoor Sports Conference (IMOSC, 2004, 2005, 2006, 2008, 2010, 2012, 2014, 2016, 2018), kterých se zúčastnili odborníci z mnoha světových univerzit.

Řada našich publikací v posledních letech se přímo dotýká výchovy v přírodě. Terminologií související $\mathrm{s}$ výchovou v přírodě se obšírně zabývala ve svých publikacích od roku 2005 I. Turčová. K terminologické tematice se v kvalitativních rozhovorech vyjadřovali britští a čeští odborníci v oblasti výchovy v prŕrodě. Ukázalo se, že je téměř nemožné přijmout jednu všeobecně uznávanou definici výchovy v prŕrodě. Pro akademické pracovníky je však nutné porozumět jiným př́stupům, které jsou ovlivněny historickými, geografickými, kulturními i společenskými poměry té které země.

V dalších studiích (Neuman, 2011, 2013a, 2013b) analyzujeme několik zahraničních variant formulování zaměření a hodnocení výchovy v přírodě. Konstatujeme, že dobře vedené programy výchovy v přírodě splňují požadavky na kvalitní náplň volného času a také souzní s učebními programy tělesné výchovy, osobnostní a sociální výchovou i výchovou environmentální. Naznačujeme, že programy výchovy v přírodě lze také propojit s výukou dalších předmětů, jako je biologie, geografie, historie a další.

V dalších příspěvcích (Neuman, 2015, 2019) se zamýšlíme nad koncepcí výchovy v př́rodě a obracíme se ke kapitole, kterou napsal pro Pedagogickou encyklopedii J. Pelikán (2009). Při vysvětlování vlivu výchovy Pelikán zdůrazňuje nepřímé pedagogické působení, které spočívá v tom, že $\mathrm{v}$ programech vytváríme problémové situace, do jejichž řešení zapojují žáci rozhodovací procesy, které jsou provázeny jejich emočními reakcemi a pedagog by měl zpětnou aferentaci žáků doprovázet reflexí.

\section{Vybrané zahraniční koncepce výchovy $\mathrm{v}$ přírodě}

Jednu z prvních rozsáhlých monografií věnovaných výchově v přírodě (outdoor education) napsal americký pedagog J. W. Smith (1955).

První vážný pokus o definici publikovali G. E. Donaldson a L. E. Donaldson (1958). Shodují se v tom, že termín výchova v přírodě (outdoor education) je běžně používaný ve dvou významech:

- jedná se o zkušenosti nabyté učením se v přírodním prostředí; 
- o vědomosti a zkušenosti získané pro zvládnutí dlouhodobějšího pobytu a pohybu v př́rodě.

Je to tedy učení se životem v př́rodě (education in the outdoors) a také učení se pro život $\mathrm{v}$ přírodě (education for the outdoors). Tyto dvě součásti či fáze výchovy v př́rodě se dle názorů autorů neustále prolínají. Nejprve se musí získat zkušenosti a prožitky, které mohou změnit určitý životní postoj. Pak nastupuje učení se dovednostem, které umožní život nebo dokonce přežití v náročných podmínkách divoké př́rody. Těchto dovedností se využívá také pro oddech a rekreaci. $V$ tomto pojetí může být pod termín zahrnuto mnoho aktivit v př́rodě od rybolovu po horolezectví, stejně tak široký záběr mủže mít poznávání přírody prostřednictvím mnoha vědních oborů od biologie ke geologii.

Později J. W. Smith (1963) navrhl další charakteristiku výchovy v př́rodě. Podle nich lze popsat výchovu v př́rodě jako education in, což předpokládá využití všech př́rodních zdrojů pro učení a výchovu. Dále je třeba uvažovat o education for, to znamená zaměřit se na ochranu př́rody a učit se dovednostem ve sportech i dalších aktivitách. Slovní spojení about the outdoors naznačuje směry učení, vztahy člověka a přírody i využívání jiných oborů. Education through outdoors naznačuje, že učení a výchovu lze podporovat skrze aktivity v přírodě, což se blíží jedné z myšlenek Kurta Hahna, který v prvních letech školy Outward Bound zdůrazňoval, že kurzy u moře nejsou zaměřeny jen na výuku jachtingu, nebot' činnosti na moři používá především jako prostředek výchovy.

Jiný pohled uplatňují D. R. Hammerman a kol. (1985), kteří akceptují výchovu v prŕírodě (outdoor education) v několika směrech:

- jako učení, proces probíhající v jiném prostředí než ve tříděči posluchárně;

- jako proces získávání dovedností prostřednictvím pohybu a pobytu v př́rodě;

- i jako sociální rozvoj umožněný prací v malé skupině osob.

První komplexní model výchovy v přírodě (outdoor education) publikoval S. Priest (1986). Upozornil na to, že téměř 30 let se nikdo nepokusil podat zdůvodněnou definici výchovy v přírodě. Kritizoval dříve publikované definice (Donaldson \& Donaldson, 1958; Hammerman et al., 1985; Smith, 1963). 
Na modelu stromu ukázal široké souvislosti výchovy v přírodě. Proces učení a výchovy se opírá o přímé prožitky a zkušenosti získávané v přírodním prostředí. Je to multidisciplinární oblast. Nejedná se pouze o učení se o přírodě, jde o to, že zde velkou roli hraje také sociální prostředí, ve kterém se tato činnost provádí. Nejedná se jen o službu přírodě, je zde také snaha o nezávislé, svobodné učení, uvažování a samostatné řešení problémů.

Ve spleti těchto vazeb lze charakterizovat několik základních spojení:

Interpersonální vztahy se týkají vazeb mezi lidmi, můžeme sem začlenit umění spolupráce, komunikace a rozvoj vzájemné důvěry mezi členy sociální skupiny.

- Intrapersonální vztahy se obracejí k jednotlivci, jedná se zde o rozvoj samostatnosti, sebedůvěry, sebepojetí a o poznání vlastních schopností a hranic.

- Ekosystemické vztahy vyjadřují dynamiku a vzájemné propojení všech prvků ekosystému (přenos energie, síly př́rody, závislost organismů).

- Ekistické vztahy vyjadřují interakci člověka s jeho prostředím. Jde o jeho působení na přírodní zdroje a zpětné působení kvality prostředí na kvalitu života společnosti.

Historicky lze vysledovat dva směry uvnitř výchovy v prŕrodě, z nichž každý je zaměřen na rozdílný pár vztahů.

Prvním z nich je dobrodružná výchova (adventure education) zahrnující aktivity $\mathrm{v}$ př́rodě tradičně zaměřené na intrapersonální a interpersonální vztahy. Cíle jsou zde dosahovány úspěšným překonáváním výzev v divoké př́rodě (nejen zde).

Environmentální výchova (environmental education) pak zahrnuje ekologické programy zaměřené na ekosystemické a ekistické vztahy. Cíle je dosaženo ve změně životního způsobu, který respektuje nezávislé vztahy všech živých tvorů a citlivou službu Zemi.

Vztahy, které se vyskytují v oblasti výchovy v přírodě, si můžeme demonstrovat na názorném př́kladu: představme si, že výchova $v$ př́rodě je velkým vzrostlým stromem (viz obr. 1). Listy tohoto stromu můžeme přirovnat k procesu zkušenostního učení. Tyto listy využívají procesů fotosyntézy, aby načerpaly energii ze slunce a přijímaly podpůrné látky ze vzduchu a půdy. 
Vzduch pak představuje obsah vzdělání, na kterém je program výchovy $\mathrm{v}$ přírodě založen a stejně jako $\mathrm{v}$ případě listů dochází i zde k výměně informací mezi procesem učení (listy) a obsahem vzdělávání. Strom je pevně zakotven svými kořeny v zemi. Země představuje smysly a tři oblasti učení. Zkušenostní proces učení směřuje od těchto smyslů a oblastí do kořenů, kde se výsledky učení ukládají.

Uvedená metafora naznačuje, že výchova $\mathrm{v}$ přírodě obvykle zahrnuje oba směry: dobrodružný i ekologický. Smíšené bývají i vztahy. Smíšený přístup $\mathrm{k}$ výchově v přrírodě proto můžeme pokládat za nejúčelnější.

Naznačené vztahy nicméně mohou vychovateli či vedoucímu pomoci rozpoznat, které hlavní cíle chce ve své práci sledovat. Těmto cílům pak musí přizpůsobit prostředí, program i metody práce.

\section{Obrázek 1}

Oblast výchovy v přírodě na modelu stromu

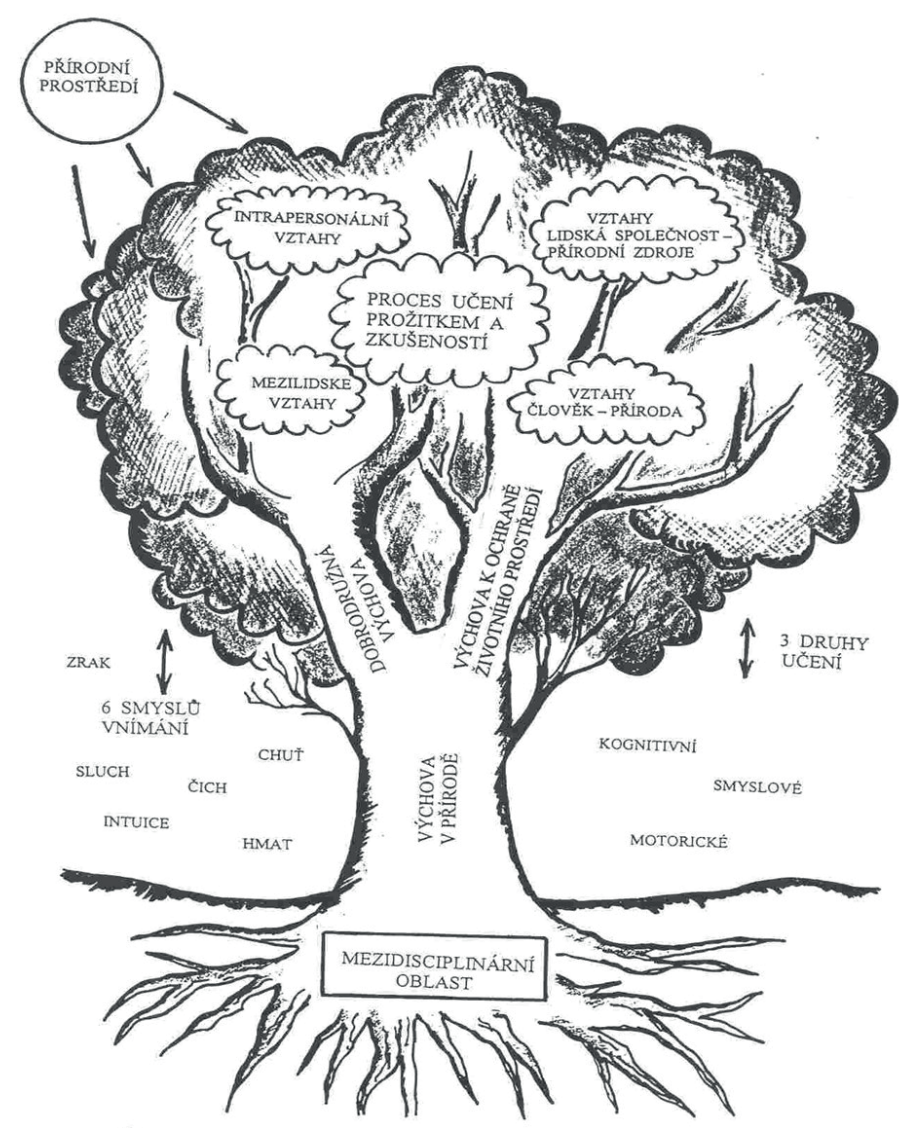

Pozn. (upraveno dle Priest, 1986) 
Další pracovní verzi konceptu výchovy v přírodě (outdoor education) popsali významní britští autoři P. Higgins a C. Loynes (1997). Na školení pro skotské vůdce $v$ prŕrodě připravili názorný obrázek, na kterém chtěli dokumentovat, že výchova $v$ přírodě není volně měnící se termín závislý na tom, kdo o něm zrovna hovoří. Přesvědčili se, že nastal čas, kdy je třeba ukázat, že výchova v př́rodě má vlastní okruh znalostí, který je mezinárodně uznáván. Výchova $\mathrm{v}$ př́rodě je podle nich oborem, který čerpá svoje pracovní zaměření ze tří okruhů. Prvním okruhem jsou aktivity v prrírodě v širokém slova smyslu, dalším okruhem je environmentální výchova a třetím okruhem je sociální a osobnostní růst.

Uvedené zdroje (okruhy) musí vedoucí programů výchovy v přírodě respektovat a ve skladbě programů využít. Je nezbytné, aby veškerá činnost respektovala také příslušná bezpečnostní pravidla. Dále je zřejmé, že rozhodnutí a hodnocení, která jsou činěna v intimním prostředí akce, nejsou nikomu veřejně svěřována. Je to také jeden $\mathrm{z}$ důležitých rysů profesionality.

Oceňujeme návrh kolegů z Velké Británie. Často se nám osvědčil při osvětlování víceoborového pojetí výchovy v př́rodě. Schéma je názorné, i když si uvědomujeme míru zjednodušení, zvláště při objasňování osobnostního a sociálního rozvoje.

\section{Obrázek 2}

Rozsah a zacílení výchovy v prírodě

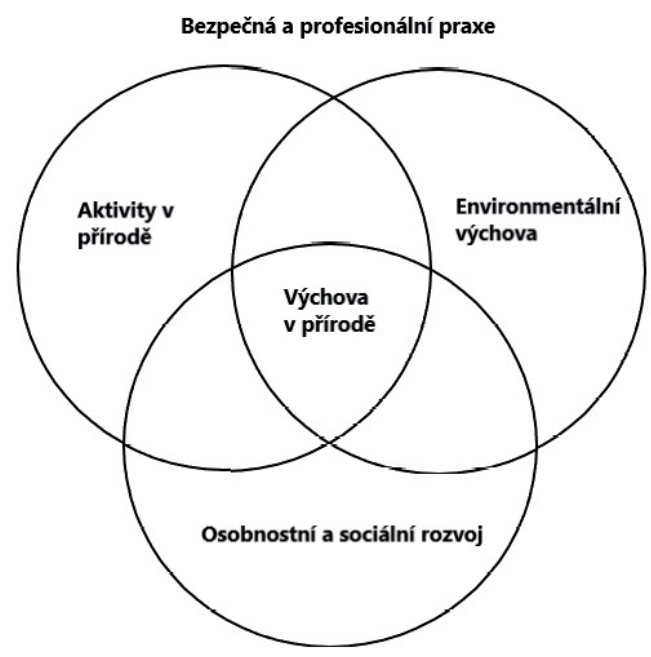

Pozn. Upraveno dle Higgins \& Loynes, 1997. 
Zpracování novější americké koncepce výchovy v přírodě (outdoor education) je př́kladem spolupráce mezi odborníky několika univerzit a environmentálních center. Gilbertson a kol. $(2006,2022)$ navrhují v podstatě stejné schéma jako britští autoři, přičemž připouštějí v jednotlivých oblastech další činnosti.

Oblasti, jako jsou ekologické vztahy, aktivity v př́rodě i osobnostní rozvoj, doplňují o novější trendy prosazované v průběhu času v americké praxi i teorii. Při popisu jednotlivých částí nedávají autoři čtenářủm bližšś informace, proč tyto oblasti doplnili a jakou má doplněk roli. Lze to však vyčíst z podrobných charakteristik jednotlivých částí schématu uváděných v obsáhlé publikaci.

Podle tohoto přístupu lze v konceptu výchovy $\mathrm{v}$ přírodě počítat $\mathrm{s}$ ekoturistikou i dobrodružnou výchovou, připouštějí propojování ekologických vztahů s formální environmentální výchovou a přidávají další typicky americký směr činnosti, a to interpretaci. Interpretace (výklad) je samostatným studijním oborem. Má přibližovat návštěvníkům historické procesy v př́rodě i v kulturním životě. Jde o výchovnou aktivitu, která má za úkol odhalit význam a vztahy využívající originální objekty, které vidí návštěvníci na vlastní oči, a mají tak prožitky z první ruky. Není to pouhá informace, nýbrž odhalování souvislostí na základě informací. Někteří považují interpretaci za umění.

Návrh představuje pragmatický počin rozšiřující záběr výchovy $\mathrm{v}$ přírodě, nebot' v předcházejícím americkém vývoji došlo taktéž k posunu od tábornických programů k široké oblasti znalostí a dovedností souvisejících s nynější výchovou v přírodě.

Výchova v přírodě (outdoor education) není ve světě jen nějaký zapomenutý směr či odnož zkušenostního učení. Více než 50 let probíhá rozvoj tohoto směru. Současně probíhají mnohé změny, které jsou patrné především v USA a Velké Británii, tedy v zemích s nejdelší tradicí výchovy v přírodě. V mezinárodním měřítku probíhají změny, které naznačují, že se konstituuje obor, který si zasluhuje pozornosti odborníků z mnoha oblastí.

Tento obor řeší vliv programů výchovy v přírodě na účastníky, adaptuje mnohé teorie (Neill, 2010) z oblasti věd o sportu, z rekreologie, pedagogiky, psychologie, sociologie, managementu, biologie i terapie. Je to vskutku víceoborový koncept, který se může dále rozvíjet díky výměně informací a vzájemné spolupráci. Ustavují se odborná fóra a různé typy koalic a asociací. Stále se udržují v mnoha zemích odborné specializované časopisy a zvětšuje se zájem 
i o studijní programy spojené s výchovou v přírodě a výchovou dobrodružnou. Příklady organizací, časopisů a studijních programů uvádíme níže.

\section{Obrázek 3}

Schéma koncepce výchovy v př́rodě

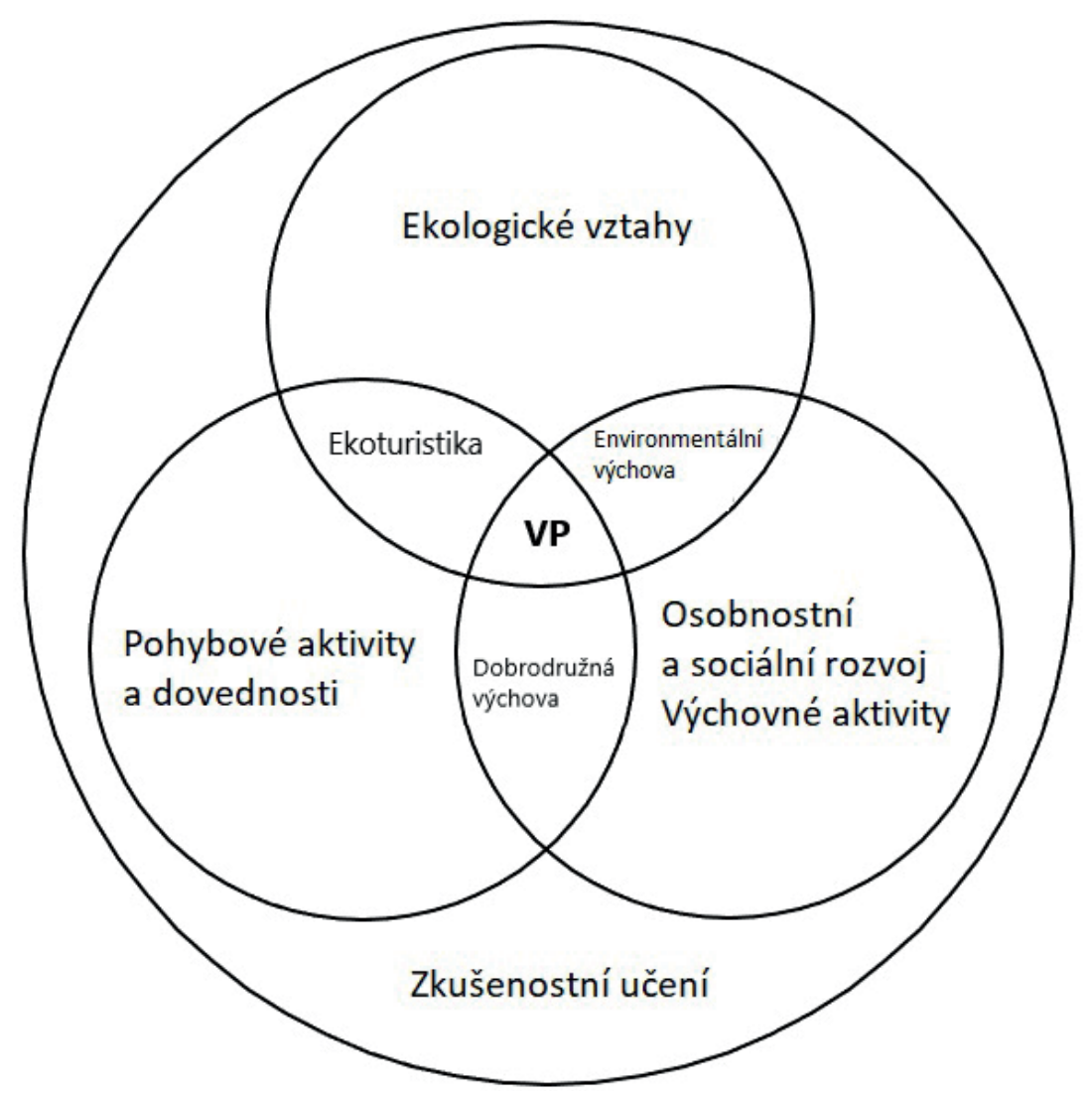

Pozn. VP - výchova v přírodě (upraveno dle Gilbertson et al., 2006).

\subsection{Odborné organizace}

Výchova $\mathrm{v}$ přírodě má především v anglicky mluvících zemích mnoho koalic, asociací či výborů (tabulka 1). Je to velká př́ležitost pro odbornou diskusi v národním i mezinárodním měřítku.

V této souvislosti je nám líto, že iniciativy pro založení určitého typu asociace vzniklé koncem 20 . století v ČR zůstaly jenom na papíre a v myslích několika entuziastů. Stále máme šanci účastnit se jednání, které nyní v rámci EU nabízí European Network of Outdoor Sports (ENOS) nebo European Institute for Outdoor Adventure Education and Experiential Learning (EOE Network). 


\section{Tabulka 1}

Přehled důležitých mezinárodních organizací ve výchově v prírodě

\begin{tabular}{|c|c|}
\hline Organizace & Stát (rok vzniku) \\
\hline $\begin{array}{l}\text { American Camp Association (ACA) /dříve American Camping } \\
\text { Association/ }\end{array}$ & USA (1910) \\
\hline Outward Bound (OB) & UK (1941) \\
\hline National Outdoor Leadership School (NOLS) & USA (1965) \\
\hline New York State Outdoor Education Association (NYSOEA) & USA (1968) \\
\hline Institute for Outdoor Learning (IOL) & $\begin{array}{l}\text { UK (1970 NAOE, } 1998 \\
\text { AfOL, } 2001 \text { IOL) }\end{array}$ \\
\hline Project Adventure (PA) & USA (1971) \\
\hline National Society for Experiential Education (NSEE) & USA (1971) \\
\hline Association for Experiential Education (AEE) & USA (1977) \\
\hline Wilderness Education Association (WEA) & USA (1977) \\
\hline American Recreation Coalition (ARC) & USA (1979) \\
\hline Experientiel - Experiential Learning / Outdoor Education France & Francie (1986) \\
\hline Coalition for Education in the Outdoors (CEO) & USA (1987) \\
\hline $\begin{array}{l}\text { Friluftslivrådenes Landsforbund (FRIFO) - Spolkový svaz } \\
\text { komunálních rad friluftslivu }\end{array}$ & Norsko (1989) \\
\hline Institut für Erlebnispädagogik & Německo (1990) \\
\hline $\begin{array}{l}\text { Center šolskih in obšolskih dejavnosti (CŠOD) - Centrum pro školy } \\
\text { a výchovu v př́rodě }\end{array}$ & Slovinsko (1992) \\
\hline Association of Outdoor Recreation and Education (AORE) & USA (1993) \\
\hline Initiative Outdoor-Aktivitäten (IOA) & Rakousko (1993) \\
\hline $\begin{array}{l}\text { National Centre for Outdoor Education (NCU) - součást Faculty of } \\
\text { Education, Linköping University }\end{array}$ & Švédsko (1993) \\
\hline $\begin{array}{l}\text { European Institute Outdoor Adventure Education and Experiential } \\
\text { Learning (EOE) }\end{array}$ & $\begin{array}{l}\text { Evropa, registrován } \\
\text { v Německu (1996) }\end{array}$ \\
\hline Outdoors New Zealand (ONZ) & Nový Zéland (1997) \\
\hline Outdoor Education Australia (OEA) & Austrálie (2006) \\
\hline Seikkailukasvatus - National Adventure Education Network & Finsko (2007) \\
\hline The European Network of Outdoor Sports (ENOS) & Evropa (2013) \\
\hline Pracownia Nauki i Przygody & Polsko (2014) \\
\hline
\end{tabular}




\subsection{Specializované časopisy}

Odborné a vědecké časopisy, které zahrnují výsledky výzkumných studií, jsou velmi prospěšné pro rozvoj každého studijního i profesního směru (tabulka 2).

Velmi kvalitní studie publikují časopisy Journal of Adventure Education and Outdoor Learning (JAEOL) nebo Journal of Experiential Education (JEE). Oba mají zkušenou redakční radu a kvalitní skupinu oponentů, do které jsou jmenováni odborníci z UK, USA, Kanady, Austrálie i Nového Zélandu. JAEOL vydává britská organizace Institute for Outdoor Learning a JEE vydává americká Association for Experiential Education.

Stále vznikají časopisy nové. Výchova v přírodě má specializované časopisy i v Kanadě, Austrálii, na Novém Zélandě nebo ve Finsku. Registrujeme trend, kdy se $\mathrm{k}$ názvu časopisu pro výchovu $\mathrm{v}$ př́rodě přiřadí environmentální či ekologická výchova. Takto např́íklad změnil název v roce 2016 australský časopis Journal of Outdoor Education na Journal of Outdoor and Environmental Education.

V Evropě se nyní podobnou tematikou zabývá také německý časopis Erleben und lernen, který reaguje na teoretické i praktické problémy spojované s Erlebnispädagogik.

V ČR již řadu let vychází časopis Gymnasion, kde se velmi často objevují články, ve kterých nacházíme souvislosti s výchovou v přírodě. Dalším odborným časopisem je Journal of Outdoor Activities, který vydává Univerzita Jana Evangelisty Purkyně v Ústí nad Labem.

\section{Tabulka 2}

Odborné časopisy zabývající se výchovou v prrírodě

\begin{tabular}{|c|c|}
\hline Časopis & Země (vydavatel) \\
\hline Journal of Experiential Education (JEE) & USA (Association for Experiential Education, od 1978) \\
\hline $\begin{array}{l}\text { Pathways - The Ontario Journal } \\
\text { of Outdoor Education }\end{array}$ & Kanada (od 1989) \\
\hline $\begin{array}{l}\text { Journal of Outdoor and Environmental } \\
\text { Education (JOEE), dříve Australian } \\
\text { Journal of Outdoor Education (AJOE) }\end{array}$ & $\begin{array}{l}\text { Austrálie (Outdoor Council Australia, 1995-2015 } \\
\text { AJOE, od } 2016 \text { JOEE) }\end{array}$ \\
\hline $\begin{array}{l}\text { Journal of Adventure Education and } \\
\text { Outdoor Learning (JAEOL) }\end{array}$ & $\begin{array}{l}\text { Velká Británie (Institute for Outdoor Learning, } \\
\text { od 2000) }\end{array}$ \\
\hline
\end{tabular}




\begin{tabular}{ll}
\hline Časopis & Země (vydavatel) \\
\hline $\begin{array}{l}\text { New Zealand Journal of Outdoor } \\
\text { Education (NZJOE) }\end{array}$ & Nový Zéland (od 2002) \\
$\begin{array}{l}\text { Journal of Outdoor Recreation, } \\
\text { Education and Leadership (JOREL) } \\
\text { Taproot Journal }\end{array}$ & USA (od 2009) \\
$\begin{array}{l}\text { Horizons } \\
\text { Research in Outdoor Education (ROE) }\end{array}$ & USA (Coalition for Education in the Outdoors) \\
$\begin{array}{l}\text { Journal of Health, PE, Recreation } \\
\text { and Dance (JOHPERD) - sekce } \\
\text { pro výchovu v prírodě }\end{array}$ & USA \\
$\begin{array}{l}\text { Erleben und lehren } \\
\text { Zeitschrift für Erlebnispädagogik }\end{array}$ & Nermeck Education in the Outdoors, od 2014) \\
\hline
\end{tabular}

\subsection{Studijní programy}

Výchova v přírodě se od počátku 70 . let 20. století stala i součástí univerzitních studijních programů v různých částech světa (Neuman, 2013a). Vysokoškolské vzdělání ve výchově $\mathrm{v}$ přírodě lze získat především $\mathrm{v}$ anglicky mluvících zemích (USA, UK, Kanada, Austrálie). V USA, UK a Austrálii jsou akreditována také doktorská studia. Postupně se však objevují studijní programy v Německu (Univerzita v Marburgu). Programy blížící se koncepci výchovy v př́rodě najdeme ve Švédsku (Dahlgren \& Szczepanski, 1998), Norsku (Liedtke \& Lagerström, 2007), Dánsku (Bentsen, 2009) a také v ČR na FTVS UK od 1992, na UPOL FTK v Olomouci (Katedra rekreologie) od roku 1994 a na PF UJEP v Ústí nad Labem od roku 2000.

Zajímavé informace se týkají rozvoje studijních programů ve Velké Británii. Tam dochází k nabídce poměrně velkého počtu studijních oborů spojených $\mathrm{s}$ dobrodružným pobytem $\mathrm{v}$ př́rodě. Roste počet oborů, které jsou spojovány s manažerskou a obchodní činností.

V následující tabulce (tabulka 3) uvádíme obory, které jsou spojeny s akreditacemi za posledních 10 let; situace se rychle proměňuje, změny se budou týkat hlavně Velké Británie, která opustila EU. 


\section{Tabulka 3}

Univerzity nabízející magisterské a doktorské programy zahrnující prevážně tematiku výchovy v př́rodě

\begin{tabular}{lc}
\hline University of New Hampshire & USA \\
\hline Texas AM University & USA \\
$\begin{array}{l}\text { Prescott College, s důrazem na adventure education } \\
\text { Plymouth State College, navazující na Project Adventure }\end{array}$ & USA \\
$\begin{array}{l}\text { Minnesota State University, se zaměřením na experiential education a s rozsáhlou } \\
\text { tematikou výchovy v př́rodě }\end{array}$ & USA \\
$\begin{array}{l}\text { Indiana University, s hlavním zaměřením na outdoor recreation / therapeutic } \\
\text { recreation a s významným vlivem výchovy v prírodě }\end{array}$ & USA \\
$\begin{array}{l}\text { University of Edinburgh Scotland, Moray House School of Education and Sport } \\
\text { University of Cumbria }\end{array}$ & UK \\
$\begin{array}{l}\text { Sheffield Hallam University, s hlavním důrazem na outdoor management } \\
\text { development }\end{array}$ & UK \\
$\begin{array}{l}\text { University of Woollongong } \\
\text { Victoria University }\end{array}$ & UK \\
$\begin{array}{l}\text { University of South Australia } \\
\text { Latrobe University, sledující také komerční využití v rámci outdoor and nature } \\
\text { tourism }\end{array}$ & Australia \\
Lakehead University, propojující outdoor and ecological experiential education & Australia \\
\hline
\end{tabular}

\section{Vymezení výchovy $\mathrm{v}$ přírodě $\mathrm{v}$ ČR}

Na základě rešerše literatury a našeho zhodnocení současných zkušeností $\mathrm{z}$ praxe v ČR se pokusíme vymezit výchovu $\mathrm{v}$ prŕírodě v ČR.

V současné době je nám blízká koncepce, kterou publikovali američtí kolegové Gilbertson a kol. (2006, 2022). Hovoří o aktivním tělesném pohybu v př́irodě. Oblast ekologické výchovy vidí autoři v širším pohledu ve vztahu k výchově environmentální. Osobnostní rozvoj spojují s ochranou a poznáváním př́rody stejně jako se schopností interpretovat poznatky z př́rody, krajiny i historie, což je blízké našemu pojetí turistiky. Hraničním polem jsou různé formy ekoturistiky.

Pro české pojetí výchovy v př́rodě je zajímavá zmínka o oblasti, kde se protínají aktivity $\mathrm{v}$ přírodě s osobnostním rozvojem; tyto činnosti zařazují autoři do okruhu dobrodružné výchovy. Mnoho našich i českých programů do této 
oblasti spadá. Často bychom je mohli nazvat dobrodružnou výchovou v př́írodě (outdoor adventure education).

Je třeba dodat, že všechny součásti programů výchovy v přírodě předpokládají aktivní účast žáků i učitelů (účastníků a vedoucích). Programy jsou založeny na získávání bezprostředních prožitků a přímých zkušeností. Samozřejmou součástí je hledání a skládání vhodných aktivit, volba odpovídajících metod a technik i posuzování zpětnovazební odezvy účastníků. Na procesy vlastní výchově v př́rodě lze nahlížet pod zorným úhlem experiential education, kdy získáváme nové prožitky a zkušenosti díky vlastní praktické činnosti.

Jak už jsme konstatovali dř́ve (Neuman, 2015), výchova v prrírodě je postup, který připomíná pedagogickou teorii nepřímého výchovného působení. Učitel či vychovatel vytvářejí situace podporující rozhodovací procesy žáků doprovázené emotivními reakcemi. Silné prožitky se pak za pomoci zpětných diskusí přetvářejí v přímé zkušenosti.

$\mathrm{K}$ takové charakteristice výchovy v př́rodě se přikláníme. Vede nás $\mathrm{k}$ tomu zhodnocení současných zkušeností z praxe, ve které stále kloubíme turistiku, sporty a aktivity $\mathrm{v}$ prírodě s pobytem, cvičením a hrami v př́rodě i ekologií.

Nově musíme začlenit do modelu kreativní tvorbu (zarámování aktivit, hraní rolí, dramatizace kurzovních př́běhů aj.) inspirovanou pohybem a pobytem v prŕírodě, což považujeme v kontextu zahraničních koncepcí za původní, český vklad.

Kurzovní či bloková výuka spojená s pobytem v přírodě byla vždy považována za plnohodnotnou výuku, která vyžaduje tvůrčí přístup učitelů i studentů.

Následující obrázek shrnuje náš návrh vymezení výchovy v přrírodě v České republice.

\section{Závěr}

Výchova $v$ prŕírodě je samostatná odborná disciplína. Učení a nové zkušenosti se opírají o bezprostřední, přímé prožitky účastníků vzdělávacího a výchovného procesu. Úzce tedy souvisí s oblastí zážitkové pedagogiky či zkušenostního učení. 
Výchova v přírodě není odtržená od života. Ve školách a organizacích se podílí na osobnostním rozvoji a sociální výchově. Zaměření programů pomáhá udržitelnému využívání přírodních zdrojů. Programy a proces výchovy v př́rodě přispívají k sociálnímu a emocionálnímu rozvoji mladých lidí a jsou silným impulsem pro zdravý životní styl (kvalita života, kondice, wellness). Výchova v př́rodě vyžaduje interdisciplinární přístup.

\section{Obrázek 4}

Vymezení výchovy $v$ prírodě

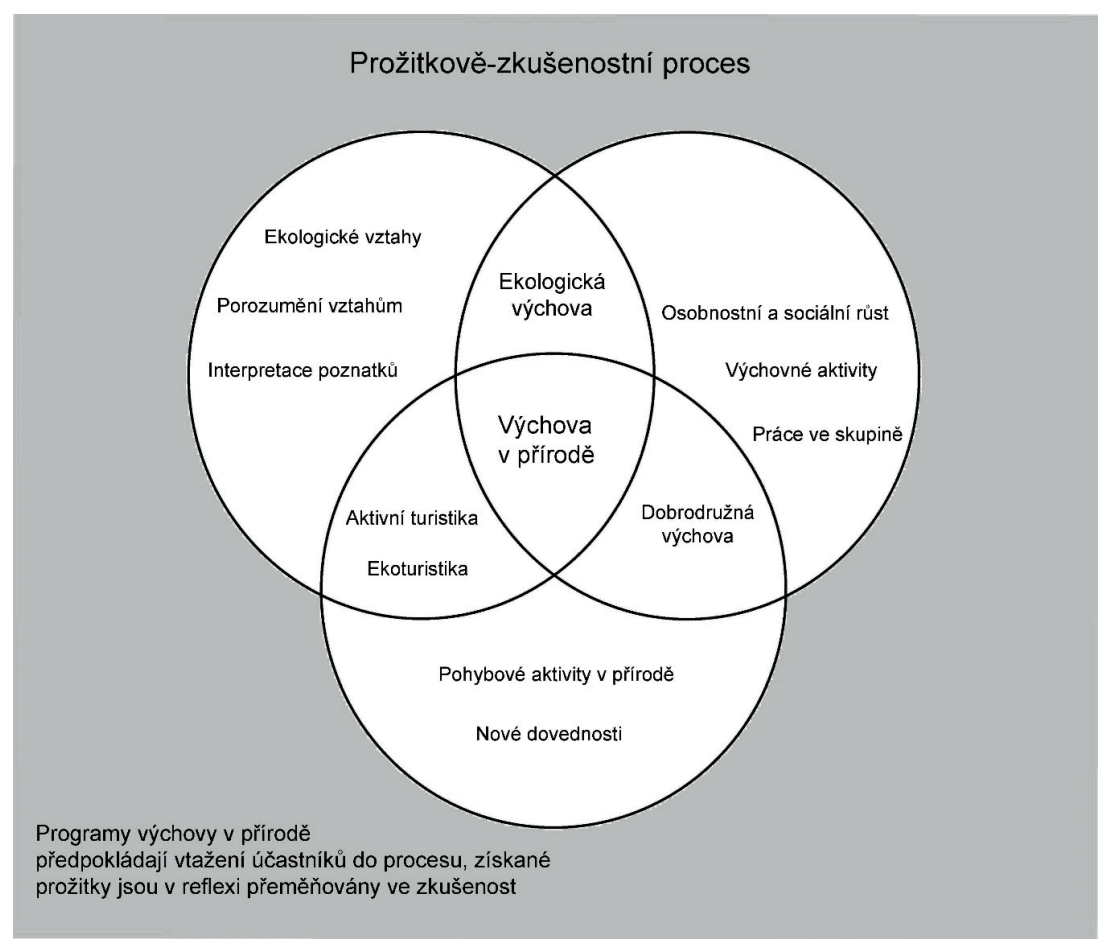

Výzkumy prokazující působení programů výchovy $\mathrm{v}$ př́rodě na rozvoj osobnosti mladých lidí (Bartůněk, 2008; Bunting, 2005; Louv, 2005; Neill \& Richards, 1998; Neuman et al., 2013) by měly vést k podpoře tohoto směru výchovného působení ve vzdělávání pedagogů i vychovatelů.

Takto široce koncipovaná výchova v přírodě může být komplexní. Musíme usilovat o to, aby všechny role př́rody dostaly př́ležitost účastnit se na procesu výchovy v přírodě. Měli bychom vést lidi, aby pro ně nebyla příroda jen kulisou, mělo by jim záležet na tom, kde a proč se pohybují. Pokud nám př́roda nahrazuje tělocvičnu, nic nám nebrání věnovat větší pozornost místu, kde se pohybujeme, a dodržovat šetrný přístup k přírodnímu prostředí. 
Ve vyspělých zemích registrujeme stále častější využívání přírody pro ozdravné programy, pro terapii i hledání míst, která nás nutí k zamyšlení. Měli bychom se naučit chápat př́rodu jako náš domov, kde budeme čerpat další inspiraci pro rozvoj a št'astný život, k tomu nás může inspirovat norský friluftsliv, jak o něm hovoří jeden ze zakladatelů studijních programů na vysokých školách Nils Faarlund (Faarlund, 2009).

Na závěr musíme konstatovat, že jsme se mohli dotknout jen malé části problémů, které je třeba $\mathrm{v}$ dalším rozvoji výchovy $\mathrm{v}$ přírodě $\mathrm{v}$ České republice řešit. Rozvoj výchovy $\mathrm{v}$ prŕrodě by si, stejně jako jiné problémy, zasloužil odborné diskusní fórum a týmové řešení problémů. Nemůžeme zůstat jen u sepisování naší skvělé dávné i nedávné minulosti. Potřebujeme výzkumné prověřování úspěšnosti a efektivnosti programů pro různé populační skupiny.

\section{Literatura}

Bartůněk, D. (2008). Systematický přehled výsledků hodnocení programů výchovy v prírodě $v$ českých zemích. Doctoral thesis. UK FTVS.

Bentsen, P., Andkjaer, S., \& Ejbye-Ernst, N. (2009). Friluftsliv, natur, samfund og peadagogik. Mungsgård.

Bunting, C. (2005). Interdisciplinary teaching through outdoor education. Human Kinetics.

Dahlgren, L. O., \& Szepanski, A. (1998). Outdoor education. Literary education and sensory experience. Kinda Education Center.

Donaldson, G. E., \& Donaldson, L. E. (1958). Outdoor education a definition. Journal Health, Physical Education, Recreation, 29(5), 17-65.

Faalund, N. (2009). Outdoor activities - Time for a paradigm-change! In I. Turčová \& A. Martin (Eds.), Outdoor Activities in Educational and Recreational Programmes (s. 61-64). International Young Nature Friends.

Gilbertson, K., Bates, T., McLaughlin, T., \& Ewert, A. (2006). Outdoor education. Methods and strategies. Human Kinetics.

Gilbertson, K., Ewert, A., Sikandar, P., \& Bates, T. (2022). Outdoor education. Methods and strategies ( $2^{\text {nd }}$ ed.). Human Kinetics.

Hammerman, D. R., Hammerman, W. H., \& Hammerman, E. L. (1985). Teaching in the outdoors. Interstate Publishers.

Hanuš, R., \& Jirásek, I. (1996). Výchova v př́rodě. Technická Univerzita Ostrava.

Higgins, P., \& Loynes, C. (1997). On the nature of outdoor education. In P. Higgins, C. Loynes, \& N. Crowther (Eds.), A guide for outdoor educators in Scotland (s. 6-8). Adventure Education and Scottish Natural Heritage.

Honzíčková, M. (1982). Rekreace v přírodě a výchova v přírodě (Diplomová práce). UK FTVS.

Končelíková, E. (1975). Sporty a pobyt v př́rodě v kapitalistických státech (USA) a jejich kritické posouzení (Diplomová práce). UK FTVS. 
Liedtke, G., \& Lagerstrom, D. (Eds.). (2007). Friluftsliv - Entwicklung, Bedeutung und Perspektive. Meyer und Meyer Verlag.

Louv, R. (2005). Last child in the woods: Saving our children from nature-deficit disorder. Algonquin.

Lutovská, Z. (1985). Problematika dobrodružných programů v př́rodě (zhodnocení zahraničních zkušeností) (Diplomová práce). UK FTVS.

Martin, A., Turčová, I., \& Neuman, J. (2007). The Czech outdoor experience: Turistika and connections to Friluftsliv. In B. Henderson \& N. Vikander (Eds.), Nature first: Outdoor life the friluftsliv way (s. 197-208). Natural Heritage Books.

Martin, A. J., Turčová, I., \& Neuman, J. (2016). Turistika activities and games, dramaturgy, and the Czech outdoor experience. In B. Humberstone, H. Prince, \& K. A. Henderson (Eds.), Routledge international handbook of outdoor studies (s. 297-306). Routledge.

Neill, J. T., \& Richards, G. E. (1998). Does outdoor education really work? A summary of recent meta-analyses. Australian Journal of Outdoor Education, 3(1), 2-8.

Neill, J. T. (2010). Outdoor education theories: A review and synthesis. https://www.slideshare. net/jtneill/outdoor-education-theories-a-review-and-synthesis?qid=e1d7fd77-7a6f42da-9e21-69aa2cdd73f7\&v=\&b=\&from_search=1

Neuman, J. (1981). Tělocvičné aktivity v přírodě v systému tělesné kultury. In Sborník $k$ 25. výročí založení FTVS UK (s. 179-182). Univerzita Karlova.

Neuman, J. (1996). Výchova v přírodě: (sborník textů). Fakulta tělesné výchovy a sportu Univerzity Karlovy.

Neuman, J. (2011). Úvodní kapitoly pro teorii a metodiku kurzů v př́rodě. Projekt Odyssea.

Neuman, J. (2013a). Osobnostní rozvoj prostřednictvím učení a výchovy v př́rodě. ACORát, 2(1), 47-67.

Neuman, J. (2013b). 0 smyslu výchovy v př́rodě. In A. Gintel (Ed.), Hranice citlivosti. 2. konference o všestranné výchově k poctě Václava Břicháčka. Praha 10. 11. 2012 (s. 39-46). Gasset.

Neuman, J. (2015). Výchova v př́rodě - učení a výchova bezprostředními prožitky a zkušenostmi. In M. Šauerová \& V. Hošek (Eds.), Zážitková pedagogika - zdroj inspirace v edukační praxi (s. 17-25). Palestra.

Neuman, J. (2019). Současný pohled na výchovu v př́rodě v ČR. In M. Švamberk-Šauerová (Ed.), Př́nosy a možnosti využití učení prožitkem a výchovy $v$ př́rodě $v$ aktuálním edukačním kontextu i v historických souvislostech (s. 28-38). Palestra.

Neuman, J., Brtník, J., Ďoubalík, P., Šafránek, J., Vomáčko, L., \& Vomáčková, S. (2000). Turistika a sporty $v$ prrírodě. Portál.

Neuman, J., \& Hanuš, R. (2007). Kristova léta školy prázdninového času. Gymnasion, 7, 17-55.

Neuman, J., \& Turčová, I. (2018). International history - Czech Republic. In S. Priest \& M. Gass (Eds.), Effective leadership in adventure programing (s. 95-97). Human Kinetics.

Neuman, J., Turčová, I., \& Martin, A. J. (2013). Czech research and international trends in outdoor experiential education. Journal of Outdoor Activities, 7(1), 74-78.

Neuman, J., Turčová, I., \& Martin, A. (2018). Education in nature programmes in the Czech Republic since 1989. In P. Becker, C. Loynes, B. Humberstone, \& J. Schirp (Eds.), The changing world of the outdoors - European reflections (s. 235-250). Routledge.

Pelikán, J. (2009). Fenomén výchova. In J. Průcha (Ed.), Pedagogická encyklopedie (s. 19-23). Portál. 
Priest, S. (1986). Redefining outdoor education: A matter of many relationships. Journal of Environmental Education, 3(17), 13-15.

Smith, W. J. (1955). Outdoor education and youth. AAHPER.

Smith, W. J. (1963). Outdoor education. Prentice Hall, Inc.

Snopek, V. (1969). Tábornická škola. ČTU Mladá fronta.

Ševčíková, J. (1983). Výchova v př́rodě (Diplomová práce). UK FTVS.

Turčová, I. (2005). Diversity in language: Outdoor terminology in the Czech Republic and the UK (Dizertační práce). UK FTVS.

Turčová, I. (2007). „Terminologická džungle“ - česká a anglická terminologie oblasti výchovy a aktivit v př́rodě. Gymnasion, 2007(8), 23-35.

\title{
Autoři
}

PhDr. Jan Neuman, CSc., Univerzita Karlova, Fakulta tělesné výchovy a sportu, Katedra sportů v př́rodě, José Martího 31, 16252 Praha 6 - Veleslavín, e-mail: neuman@atlas.cz

PhDr. Ivana Turčová, Ph.D., Univerzita Karlova, Fakulta tělesné výchovy a sportu, Katedra sportů v přírodě, José Martího 31, 16252 Praha 6 - Veleslavín, e-mail: turcova@ftvs.cuni.cz

Mgr. Tomáš Brtník, Univerzita Karlova, Fakulta tělesné výchovy a sportu, Katedra sportů v prŕrodě, José Martího 31, 16252 Praha 6 - Veleslavín, e-mail: tbrtnik@ftvs.cuni.cz

Prof. Andrew J. Martin, Massey University, Palmerston North, New Zealand, e-mail: a.j.martin@massey.ac.nz

\section{Development of the concept of education in nature in the international context, and its definition in the Czech Republic}

\begin{abstract}
Interest in 'education in nature' in the Czech academic sphere has begun to rise with the accreditation of study specializations or programmes under the names "Outdoor activities" or "Outdoor education", or the inclusion of subjects of similar names into university study programmes. The aim of this review is to introduce the development of the concept of education in nature, výchova v prírodě, in the Czech environment using the background of international literature and outdoor contexts. Selected theories of outdoor learning are analysed and evaluated. We then try to define 'education in nature' in the Czech Republic. Comparing the focus of our work with different theories internationally, we found similarities to the outdoor and environmental education, and personal and social development focus of Gilbertson et al. $(2006,2022)$.
\end{abstract}

Keywords: outdoor activities, environmental education, personal and social development, outdoor learning 